\title{
Memorial for Dad
}

\author{
Mark Tollison ${ }^{1}$
}

Received: 1 November 2016/Accepted: 31 January 2017/Published online: 6 March 2017

(C) Springer Science+Business Media New York 2017

For those of you who don't know me, my name is Mark and I am Bob Tollison's son. I would like to begin by thanking everyone for being here today and spending time with my family to remember and honor my father.

Over the past years, my father's numerous accomplishments have been recognized in many distinctive ways and venues. And again, now upon his passing, we know him as a renowned and well-respected teacher, researcher, writer, economist. And the written history will reflect his great work and legacy. But, Dad has an additional legacy well recognized by his family and friends, as a devoted husband; as a sturdy, durable father figure; as a mentor; and as an ever loyal friend.

To a small child and on into teenage years, Dad always seemed larger than life. An immense presence. You knew when he was in the room. Seemingly always engaged in diligent and productive effort. Always all about economics and public choice. But then, catch him in another setting, and he was entertaining and unreservedly gregarious. If you hung in long enough you could see and maybe participate in the full spectrum of Bob Tollison. At times it felt like latching onto a shooting star and trying to hang on for the ride.

Dad was a lover of sports and competition. Not just as an avid follower of games but also as a true athlete. His skills were borne out of the red clay dirt on the courts and fields of play in Spartanburg. A dead-eye set shot in basketball, a maddening first step that could not be defended, a decisive stroke on the tennis court, Dad loved competing and loved to play.

Before I press on, we need to come to a confession about Bob Tollison. He was no saint. It is not going to be right if someone doesn't stand up here and apply some truthful descriptions. Dad could be as stubborn as a pack of mules, at times a real stick in the mud... very difficult to move, and a touch on the "thrifty" side. Plus, some of you may know that Dad had a bit of a temper. My grandmother, Mama T, once referred to it as "that

Mark Tollison

mtollison@greenvillecounty.org

1 Greenville, SC, USA 
Tollison Temper." I know about this thing, I have long been told by reliable family authorities that I have the temper gene too.

It is before my time, but legend has it that Dad's temper and love of basketball would at times intersect in his starring role for the Spartanburg High Redbirds basketball team. The Spartanburg Herald even noted the dilemma in a news account when Spartan High Coach Wally Dean would have to bench Dad, one of his best players. Not because of poor play, but for what we might call today "anger issues" on the court. But as has been retold to me countless times over a life, the Spartan High student body in attendance recognized the need for scoring and would cajole Coach Wally Dean to put Dad back in the game with a collective cheer of "Golly Wally We Want Tolly!" Maybe the Lord heard that call and has brought Dad up into the ultimate game.

It seems to me that Dad never quite knew what to do with toddlers and little children, but once you reached into your teenage years and young adulthood ... you got the full Bob. And then, the long, brilliant conversation began. First between father and son; and then later between father and daughter. Dad would always push you or test you even in the smallest moment, but he was always willing to play. I know that April and Anna would prank Dad on occasions and he was usually a pretty good sport about it.

One time when I was out of college visiting and April was in high school, into the evening Dad just kept peppering April and I with all of these various questions and challenges putting us on the spot. We kept answering him, until finally Anna spoke up in our defense and asked Dad why he was keeping this up. Dad said, "I expect my children to be able to get through a press conference." For all of Dad's libertarian and conservative leanings, he was in so many ways very unconventional. And that unconventionality extended to his fatherly "guidance".

Here is the snapshot of my Dad that I am not sure I have ever retold, but it comes back to me now because it touches on him at so many levels. Dad and I would play basketball and tennis against each other nearly every day we were together with free time. Dad's main sport was basketball and mine was tennis. I was a very motivated varsity high school tennis player. I kept pinging on him about my need for a fancy Wilson Jack Kramer tennis racket. I can't recall the price, maybe $\$ 45.00$ without strings. The Jack Kramer was the "Cadillac" of rackets back then. Sunny summer afternoon in Blacksburg Virginia, Dad takes off from the Center and we are going to play tennis. But Dad needs a racket to play so the first stop was the K-Mart off Price's Fork Road at the mall. Now, Dad goes into K-Mart and immediately buys the cheapest pre-strung wood racket for sale. It was a Winfield, made in Canada and it cost retail maybe \$5.00. We get over to the courts on the Virginia Tech campus and the gloves are off from the get go. Dad is thundering away at me with wellplaced strokes and taunting me all along, dancing around the court with his arms raised after every good shot. He declares himself to be the "Winfield Pro of Canada" with every winning stroke off this cheap racket. Between his inspired play and my bruised ego, I crumbled like a week-old cookie. Set went 6-1 to Dad and K-Mart. I was infuriated and deflated. Dad fully rubbed it in all the way home, going on and on about the strength and superiority of Bob Tollison, the Winfield Pro.

A lot of Dad, Bob Tollison, right there in that tennis set back in 1977. The athlete, the competitor, tight with money, cleverly humorous, and rowdy ... through it all teaching me the valuable lesson ... it's not the equipment, it's the player. A few years later back in Texas, my doubles partner and I won our way through Zone, District and Region and ultimately got to the State High School Tennis Championships in Austin. But I never forgot the Blacksburg Beating I took from the Winfield Pro, my Dad. 
Dad never forgot where he came from, everyone worked, everyone pulled their weight. His brothers, my Uncles, Ben and David Tollison can tell you. For all of the rough edges, Dad had a big heart. Never one to dote, still you could see just being around him how very much loved his grandchildren, Zachariah, Annabel and Katie. The family we are came about because at a crucial juncture in his personal and professional life he had the incredible fortune to have found a great teammate in Anna. Maybe it has become oldfashioned to say that behind every great man is a great woman, but April and I saw the adage in action. Dad and Anna have been a wonderful, precious example to me and my wife Sarah Jane, and to April and her husband Rich, on how to live and thrive in a relationship for the long run .... and there is no price tag that can be put on that. You can't pick that up at K-Mart.

My sister April and I learned a lot from Dad. We enjoyed our seemingly endless teasing and banter with him. He left a big footprint, but never expected us to step in and fill it up. Dad might poke or prod you to some direction, but in the end he was always willing for us to take our own paths. He loved to hear of our successes and was always available to help us whenever we needed support. But to the degree we could lift ourselves up, that was the most pleasing to him.

Well now, today we are here to remember the life of my father Bob Tollison, who I will miss greatly. It is difficult to picture what going forward will be like without his advice and encouragement. Everyone loved and respected him so much. He would not want us to mourn too much or too long, Dad was never one for a big fuss, especially over him. So let's not forget the time he shared with us, the lessons he taught us, and hold tight to the memories we had together.

Thank You. 